例

特異な合併症を伴った外傷性横隔膜破裂 2 症例の検討

$$
\begin{aligned}
& \text { 近幾大学附属救命救急センター（本部長：安富正幸） } \\
& \text { 小川雅昭”高橋均北野昌彦 } \\
& \text { 泉本 源太郎”波江野善昭 中村洋介 } \\
& \text { 坂田育弘”安富正幸1) }
\end{aligned}
$$

外傷性横隔膜ヘルニア(以下 TDH と略)は比較的稀な疾患であるか，最近の交通事故 の增加や診断技術の向上とともに, 報告例も増加してきている.我々はTDH のために胃 溃瘍の増悪から穿孔性胸膜炎を併発し, ショックに陥った症例と, 心重内血腫による心 フンポナーゼを合併した稀な症例を経験した。一ルニフの修復に加えて，胃切除及び心 膜切開にていずれる救命しえている。

横隔膜損傷はそれ自身単独で発生する事が $13 \sim 30 \%$ 上少く，多くは合併損傷を伴って いる. 脾破裂, 血気胸, 骨盤, 四肢, 肋骨骨折等を合併している事が多いが, 今回の上 らな合併症は非常に稀で, 報告ははとんどない，横隔膜損傷には開放性損傷と非開放性 損偤があるが，日本では5.5：1 と非開放性損賃が仕到的に多い. 男女比は約 5：1 1 男 性に多く，20－50歳代に多く認められる。

来引用語：外傷性横隔膜へルニフ, 穿孔性胃潰瘍, 心黄内血腫

\section{I. 緒 䨐}

胸腹部の穿通性外偤あるいは鈍的外傷の際に横隔膜 が損傷される事は此較的稀であり，しかも初診時には 合併する他の損傷に隠されて見逃される場合も多い， しかし最近の交通事故の増加と共に，また診断技術の 向上と共に報告例も増加してきている，我々は，交通 外傷による外倡性横隔膜ヘルニア（Traumatic Diaphragmatic Hernia 以下 TDH と略）で，特異な合併 症を起こした 2 症例を経験したので報告する。

\section{II. 症 例}

症例 $1 ： 57$ 瓷, 男性, 公務員.

主訴：呼吸困難, 胸痡.

家族歴：特記すべき事なし。

既往歴：28歳，肺結核，55煘，胃漬瘍にて内服治療.

現病歴：昭和58年11月 6 日, 軽自動車を運転中, 右 折時に直進乗用車に助手席側上り衝突された。この事 故で骨盤骨折, 助骨骨折の診断にて近医入院. 入院翌 日より心窝部痛があり，3 週間目頃よりタール便が持 続していた，食事は三分邪を食へてていたが，あまり摄 取できなかった。12月19日タ方，トイレ歩行時に突然

1) 近畿大学第 1 外科
呼吸困難となり，全身の疼痛を訴え，鎮痛剤にても軽 减せず，12月20日，呼吸循環不全をきたし，当救命救 急センターに転送されてきた。

入院時所見：顔面荅白, 苦䦥様顔貌, 左肺呼吸音聴 取不能，心霄部に圧痛を認めるが，腹部は比較的平担 軟.

検查所見：WBC $8,700 / \mathrm{mm}^{3}, \mathrm{RBC} 436 \times 10^{4} / \mathrm{mm}^{3}$, $\mathrm{Hb} 11.6 \mathrm{~g} / \mathrm{dl}, \mathrm{Ht} .36 .0 \%, \mathrm{pH} 7.431, \mathrm{PCO}_{2} 26.5$ $\mathrm{mmHg}, \mathrm{PO}_{2} 85.1 \mathrm{mmHg}, \mathrm{BE}-5.0 \mathrm{mEq} / l\left(\mathrm{O}_{2}\right.$ 吸入 中), $\mathrm{Na} 127 \mathrm{mEq} / l, \mathrm{~K} 4.0 \mathrm{mEq} / l$, amylase $48 \mathrm{I} . \mathrm{U}$., GOT 12I.U.

以上の如く臨床検査所見では特に異常は認めなかっ た.

他院での第30病日の胸部レントゲンでは左下肺野に 胃胞の陰影が認められたが，当院入院時の写真では左 肺野全体に暗く浸出液の眝留が認められた(Fig. 1a). そのため胸腔穿刺を施行すると，淡黄褐色膿性の胸水 約 $1,500 \mathrm{ml}$ が吸引され，その性状より胃液中心の消化 管内容液である事が確認され，胸腔内での上部消化管 穿孔が疑われた。 そこでガストログフィンによる上 部消化管透視を施行したところ (Fig. 1b)，左胸腔内 で胃体部より造影剤の流出が認められた。 
従って過去に胃潰瘍の既往もあるため，左横隔膜へ ルニフに穿孔性胃潰瘍の合併による左膿胸と診断し, 同日開腹術を施行した。

手術所見：開腹所見で腹腔内には腹水および膿はは とんど認められず，胃および脾は左胸腔内に嵌頓して

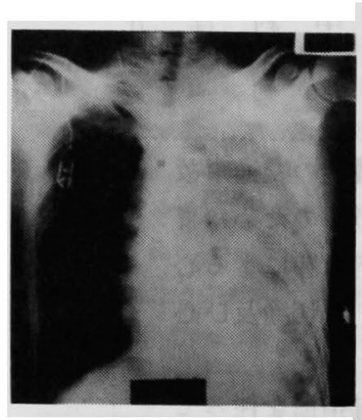

a

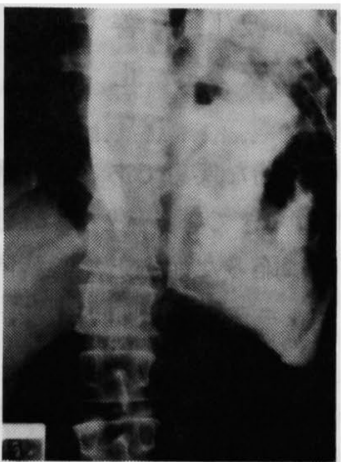

b

Fig. 1a chest X-p post traffic accident just before operation in No. 1 case.

Fig. 1b upper G-I series with gastrografin. (leakage of contrast medium from stomach)

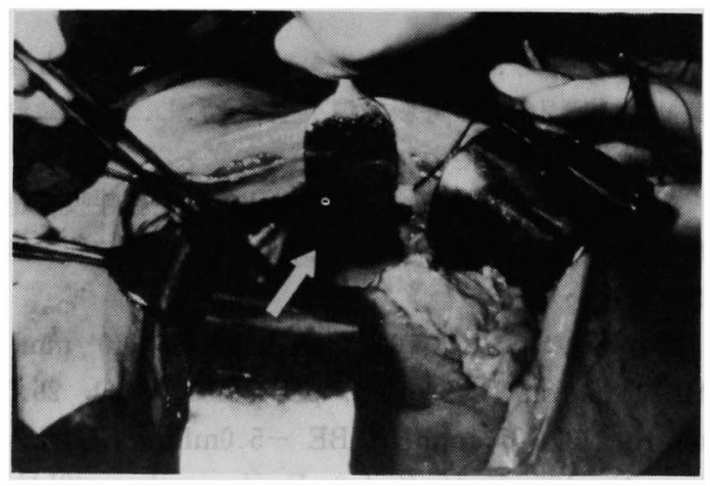

Fig. 2 rupture of diaphragma.

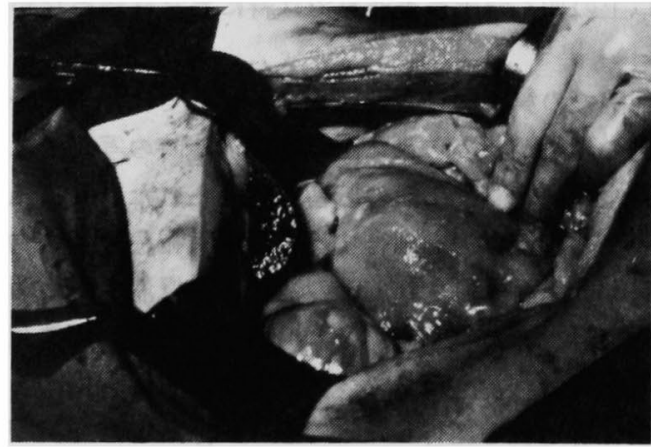

Fig. 3a perforation of stomach.
おり，腹腔から胃は前庭部のみしか認められなかった。 横隔膜は左後外側より右前方に向って，約 $8 \mathrm{~cm}$ にわ たって裂傷を認め，その創に直角に約 $3 \mathrm{~cm}$ の切開を加 之, 脱出臟器を腹腔内に還納した（Fig. 2)，腹腔側よ り胸腔内を多量の生理食塩水で洗浄した後, 横隔膜を 2 号デキンンにて修復した。胃は非常に浮腫が強く， 胃体中部小弯に穿孔部が認められ，幽門側胃切除術を 施行した（Fig. 3a），切除胃では直径 $3.5 \mathrm{~cm}$ の潰瘍底 に約 $1 \mathrm{~cm}$ 径の穿孔が認められた (Fig. $3 \mathbf{b}$ ).

術後経過：経過良好にて術後21日目に軽快退院し た.

症例 $2: 61$ 歳, 女性, 主婦.

主訴：呼吸困難, 左胸部痛, 腹痛.

家族歴：特記すべきことなし。

既往歴：特記すべきことなし。

現病歴：昭和58年 5 月 8 日, 乗用車左助手席に乗用 中，右折時に時速約 $70 \mathrm{~km}$ で直進してきた乗用車に左 側面より衝突され受傷。左多発助骨骨折，左大腿骨頝 部骨折，骨盤骨折の診断で近医入院した，受傷約 7 時 間後に強度の呼吸困難，血圧低下，頻脈をきたしたた め, 当救命救急センターに入院した。

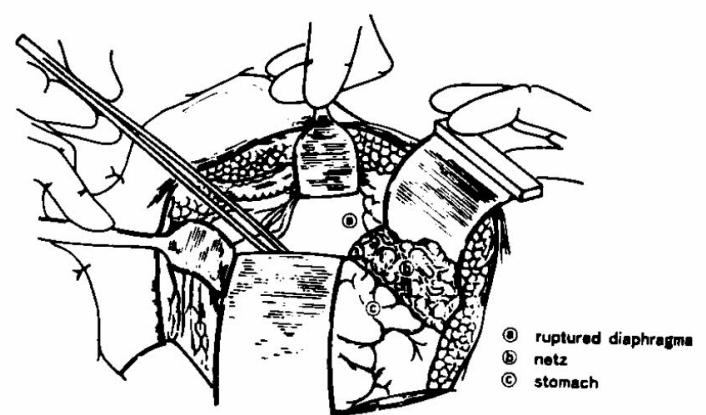




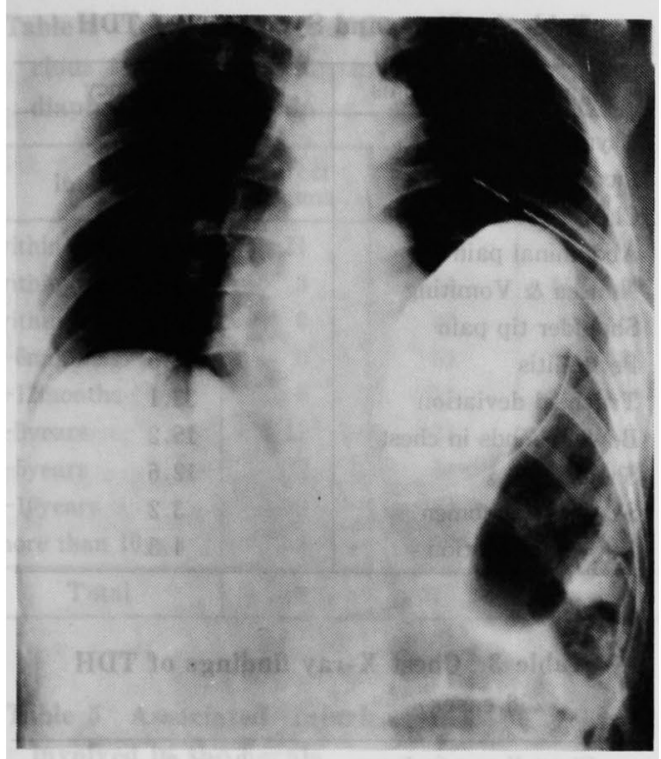

Fig. 4 chest X-p just before operation in No. 2 case.

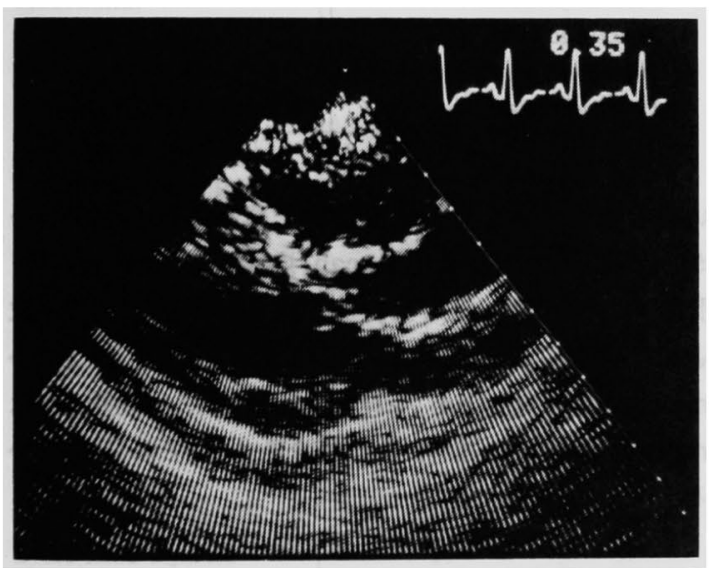

Fig. 5 pericardial effusion in cardioechogram.

現症：苦閵様顔貌で意識はやや不明瞭，脈拍112/分 整, 呼吸数28/分, 胸式努力型呼吸. 左肺野で呼吸音聴 取できず，左肩へ放散する胸痛強度であるが，腹部は 平担軟であった。

検査所見：入院時の動脈血ガス分析では $\mathrm{pH} \mathrm{7.375,}$ $\mathrm{PO}_{2} 35.0 \mathrm{mmHg}, \mathrm{BE}-7.0 \mathrm{mEq} / l$ と呼吸性フシドー シスを示した。 CPK $1.710 \mathrm{U} / l, \mathrm{LDH} 660 \mathrm{U} / l$ と著明 に上昇していた，胸部レ線では綎隔の右側移動，左肺 野に胃胞のガス像，左第 8 - 10肋骨骨折，また左胸腔 内に液貯留像を認め(Fig. 4), 胸腔穿刺を施行し血性 貯留液 $150 \mathrm{ml}$ を認めた。また心ェコーグラムにおいて
心の5内に血液によると思われる echo free spaceを 認めた(Fig. 5)，心タンポナーデを伴った外傷性横隔 膜へルニアと診断し, 直ちに贀急手術を行った。

手術所見：左第 7 肋間上り開胸した。横隔膜左肋弓 付着部前面から後面にかけて約 $20 \mathrm{~cm}$ の裂傷を認め, 胸腔内に胃底, 体部, 大網, 脾缄を認めた。脱出缄器 を腹腔内に還納し，横隔膜破裂部を修復した．次に心 表切開を施行し，中等量の血液を認めた。胸腔ドレナー ジを施行し閉胸した。

術後経過：順調で，23日目に骨折後のリハビリテー ションのため他院へ転院した。

\section{III. 考 察}

外傷性横隔膜ヘル $=>$ (Traumatic Diaphragmatic Hernia)は，1541年 Sennertus ${ }^{1)} に よ り$ 初めて報告され た。しし死亡前に診断されたのは1853年の Bowditch ${ }^{23}$ が初めてで, 1886年 Riolfi'が初めて TDH の修復に成功している. しかし系統的に診断治療がな されるよらになったのは約50年余り前からである。外 傷性の横隔膜損傷を生ずる頻度として，Brooks (4)胸 部外傷中の 4 ～5\%とし, Drews ら ${ }^{51}$ は外傷患者の $5.8 \%$ ，また益子ら ${ }^{61}$ は 1 大学救命センターで扱かった 全外傷例1.190例中, 胸部外偤236例そのうち19例 (8.1\%) に横隔膜損偒を認めている。

横隔膜損傷の発生機序として，ナイフ，銃弾などに よる直接的開放性損傷，打撲，压挫，転落などによる 間接的非開放性損傷やその他，手術侵襲後やトレーン による王迫壊死等医原性のものも認められる，TDH 発生機序における頻度の差は，年代による社会情势の 変要, 国情, 病院の立地条件等に左右されるか;，茂木 ら"は27例中13例 $(48.1 \%)$, Payne ${ }^{8)}$ は36例中25例 (69.4\%)，Ball ら9によると42例中 21 例 $(50.0 \%)$ と鈍 的外傷と鋭的外䅞に由来の TDH はほほ $1 ： 1$ の割合 となっている，笠原ら ${ }^{101} の$ 統計によると日本における TDH 324例では5.5：1 と王倒的に非開放性外侮由来 の例が多くみられている。これは日本では，銃創など が少く，交通事故が多いためと思われる，著者らの集 計したところによると本邦報告393例を年龄・性別に分 類すると男女比は4.58：1 と男性に多くみられ，年龄 は 1 -88歳と幅広くみられるが20－50歳代に多く，平 均34.1歳である。受侮原因では交通事故が58\%と最も 多く認められた。特に最近の報告では交通事故の占め る割合が増加してきている。

TDH はその85 95\%が左側に生ずると言われてい るが，患者の集計で部位記戴のある381例中左330例, 
Table 1 Frequency of the herniated viscera

\begin{tabular}{l|r}
\hline \multicolumn{1}{c|}{ Viscera } & No. of Pts. \\
\hline Stomach & $232(72.5 \%)$ \\
Colon & $201(62.8 \%)$ \\
Greater omentum & $164(51.3 \%)$ \\
Small intestine & $113(35.3 \%)$ \\
Spleen & $112(35.0 \%)$ \\
Liver & $66(20.6 \%)$ \\
Gall bladder & $8(2.5 \%)$ \\
Duodenum & $6(1.9 \%)$ \\
Pancreas & $5(1.6 \%)$ \\
Appendix & $3(0.9 \%)$ \\
\hline \multicolumn{1}{c}{ Summary } & 320 \\
\hline
\end{tabular}

右51例で左側が86.6\%を占めている，その理由として 右側には腹空内最大の実質葴器である肝があり，非開 放性損傷において横隔膜が損偒を受けにくく，左側の 横隔膜は腹圧の变動により上下に移動しやすくなって いるためと考えられる。横隔膜損傷の好発部位として

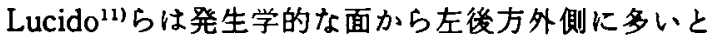
述べているが，我々の释験した症例も，同部位に認め られた。

横隔膜の脱出䑏器を見ると Table 1 のごとく部位 記載320例中，胃か樶も多く232例（72.5\%）に単独立 たは複数で認められた。TDHの臨床释過は Adamthwaite $\left.{ }^{12}\right) は$ acute phase (1a, 1b), delayed phase (2a, 2b, 2c) と大きく 2 期に分類しているが， 本邦では多くは 3 期に分けられる事が多い，第 1 期は 受賃直後で, 合併損侮が出血, shock などの病像に覆れ てTDH の存在自体が見逃されやすい状態。第 2 期は 安定鎮静化した時期，第 3 期は脱出成器の莰頓によっ ておころ校拒, 閉塞, 埢死, 出血, 穿孔等の症状が発 見する時期である。

症状としては Table 2 のごとく，呼吸困難，胸痛， 腹痛等がよく認められるが各著者の報告により異なり 一定していない．また無症状のものも 1 割程度認めら れる.

TDH の診断において Table 2のよらな臨床所見も 重要であるが，最も重要な所見は胸部単純レ線像であ る. Table 3 の上うに横隔膜の挙上や胸水の詝留, 肋骨 骨折などが過半数を占め，胃や腸管などの腹腔内葴器 が胸部に見られる事も多い。そして異常を認めないの はわずか7.5\%である。それ以外に助骨横隔膜の不鮮明 化, 綐隔偏位, 肺挫傷，肺萯胞等が胸部レントゲン診 断上の所見となる。また胸部レントゲンで診断できな
Table 2 Signs and Symptoms of TDH

\begin{tabular}{l|c}
\hline \multicolumn{1}{c|}{ Signs and Symptoms } & \% of frequency \\
\hline Asymptomatic & 9.1 \\
Increasing dyspnea & 56.4 \\
Chest pain & 37.7 \\
Abdominal pain & 36.7 \\
Nausea \& Vomiting & 32.5 \\
Shoulder tip pain & 36.5 \\
Peritonitis & 31.5 \\
Tracheal deviation & 33.1 \\
Bowel sounds in chest & 15.2 \\
Shock & 12.6 \\
Scaphoid abdomen & 3.2 \\
Bowel obstruction & 4.3 \\
\hline
\end{tabular}

Table 3 Chest X-ray findings of TDH (256 cases)

\begin{tabular}{l|c}
\hline \multicolumn{1}{c|}{ Chest X-ray findings } & \% of frequency \\
\hline Normal chest X-ray & $7.5 \%$ \\
Diaphragmatic elevation & 64.2 \\
Pleural effusion & 66.3 \\
Fractured ribs & 53.3 \\
Herniated viscus & 43.9 \\
Pneumothorax & 33.2 \\
\hline
\end{tabular}

い場合でも，多くは消化管造影で診断される事が多い が，それ以外でも胸部 CT scan, 血管造影, 気腹造影13), 肺肝シンチグラム，また特殊な例として腹腔鏡(1)や最 近では ${ }^{198} \mathrm{Au}$, Technetium 99m sulfer colloid ${ }^{1617)},{ }^{131}$ I. macroaguregated albumin ${ }^{18}$ 等を使用した radioactive scanを利用した診断すすすめられてい ろ.

受䅞から診断治療までの期間をみると，症例により 極端な差が認められる。

本邦333例を分析すると, Table 4 のごとく24時間以 内が最も多いが，6力月以上経過してから手術されて いる症例は114例 $(34.2 \%)$ にすのばる．中には10年以 上経過してから診断治療されるすのも1割程度認めら れる。 また開放性の方が早く治療されている。これは 体外よりの創が存在する事によると思われる。

横隔膜損傷はそれ自身単独で発生する事が少く (13〜30\%)，多くは合併損傷を伴っている。脾破裂， 血気胸, 骨盤, 四肢, 肋骨骨折等を合併している事か; 多い.TDHはそれ自身の症状で病院を訪れたり，搬送 されたりする事もあるが，合併損傷の症状や治療の目 的等で入院する事す少くない（Table 5)，従って，予 
Table 4 Interval between the onset of the suspicious trauma and the surgical repair of the diaphragmatic hernia

\begin{tabular}{l|c|c|c}
\hline \multicolumn{1}{c|}{ Interval } & $\begin{array}{c}\text { Direct } \\
\text { trauma }\end{array}$ & $\begin{array}{c}\text { Indirect } \\
\text { trauma }\end{array}$ & Total(\%) \\
\hline within 24hs. & 21 & 69 & $90(27.0)$ \\
within 1w. & 3 & 41 & $44(13.2)$ \\
within 1m. & 0 & 23 & $23(6.9)$ \\
1-6months & 9 & 53 & $62(18.6)$ \\
7-12months & 6 & 12 & $18(5.4)$ \\
1-3years & 11 & 21 & $32(9.6)$ \\
3-5years & 2 & 14 & $16(4.8)$ \\
5-10years & 3 & 14 & $17(5.1)$ \\
more than 10ys. & 3 & 28 & $31(9.3)$ \\
\hline \multicolumn{1}{c|}{ Total } & 58 & 275 & 333 \\
\hline
\end{tabular}

Table 5 Associated injuries with TDH not involved in the hernia

\begin{tabular}{l|c|c}
\hline \multicolumn{1}{c|}{ Associated injury } & $\begin{array}{c}\text { No. of Pts. } \\
\text { in other countries }\end{array}$ & in Japan \\
\hline Abdominal & 42 & 33 \\
Ruptured spleen & 21 & 18 \\
Ruptured liver & 12 & 16 \\
Renal contusion & 2 & 1 \\
Ruptured bladder & 11 & 9 \\
Erforated intestine & & \\
Chest & 40 & 30 \\
Pneumo-or hemothorax & 14 & 8 \\
Flail chest & 4 & 2 \\
Myocardial contusion & & \\
Skeltal & 28 & 44 \\
Fractured pelvis & 48 & 51 \\
Limb fractures & 16 & 76 \\
Rib fractures & 10 & 15 \\
Vertebral fractures & 10 & 17 \\
Svere head injuries & 160 & 290 \\
\hline$\quad$ No. of TDH & & \\
\hline
\end{tabular}

後も多くは合併病変に左右されている。死亡率は， Adamthwite らによると61例中，3.2\%と低く，多くは 14 20\%程度とされるか，合併損傷の少い開放性損傷 由来の症例が多いほど死亡率は低いとされている．著 者らの症例は 2 例とも合併病変のためにショックに 陷ったが，治療により救命できている.

手術術式には開胸, 開腹, 開胸腹の 3 法があるが, いずれも長所短所がある。開胸だけでは, 腹腔内烚器 の検索が不可能で広範な横隔膜の損傷を修復するのに 視野が狭いといら欠点がある。 また開腹手術だけでも，
心・肺等の損傷の確認ができないといら可能性がある. 開胸開腹合併手術は侵獎が大きくなるといら久点があ る。一般に手街的フプローチに関しては，急性期では 開腹，严急性期ないし慢性期では開胸と言われてい $ろ^{19220)}$.これは腹腔内合併損傷が多い事や，急性期では 胸腔内に陥入したヘルニフ臓器が胸腔内で癁着する事 が少く，開腹のみでる容易に胸腔より還納できるため である。また術者により，胸部外科医は経開胸的アプ ローチが主になるという可能性も少くない.著者らは, 穿孔性胃潰瘍を伴った症例を開腹で，心谼内血腫を 伴った症例を開胸で手術を行っている，手術的フプ ローチに関しては絶対的なものはなく，診断技術の進 歩した今日では，胸部合併症のある時は開胸で，また 広範な胸腹部の損傷がある時は開腹手術を行って，必 要により開胸または開腹を追加すればよいと著者らは 考えている。

\section{IV. 結 語}

外傷性横隔膜へルニアは，最近の交通事故の増加と 共に症例数す增加してきているか，我々は TDH のた めに胃溃晹の增悪から穿孔性胸膜炎を併発し、ショッ クに陥った症例と，心琵内血腫による心タンボナーデ を合併した稀な症例を経験したので，文献的考察を加 えて報告した。

本論文の要旨は第43回近機数急医学研究会 (1984年 3 月) において発表した。

\section{文献}

1) Sennerutus, cited by Reid, J.: Diaphragmatic herrnia produced by a penetrating wound. Edib. Med. Surg. J., 53 : 104-107, 1840.

2) Bowditch, H.I.: A treatise on diaphragmatic hernia. Buffalo Med. J. Surg., 9 : 65-94, 1853.

3) Hedblom, C.A.: Diapharagmatic hernia. J.A. M.A., 85 : 947-950, 1925.

4) Brooks, J.W.: Blunt traumatic rupture of the diapharagm. Ann. Thorac. Surg., $26: 199-203$, 1978.

5) Drews, J.A., Mercer, E.C. and Benfield, J.R.: Acute diaphragmatic injuries. Ann. Thorac. Surg., $16: 67-78,1973$.

6）益子邦洋, 村上 昌, 大塚敏文他：横隔膜の外偪, 日臨外会誌，42：640-646，1981.

7）茂木正寿，山本修三，須藤政彦：横隔膜損偤，外科 訏療, $4: 455-461,1982$.

8) Payne, J.H. and Yellin, A.E.: Traumatic diaphragmatic hernia. Arch. Surg., 117: 18-24, 
1982.

9) Ball, T., McCrory, R., Clements, J.L., et al. : Traumatic diaphragmatic hernia. A.J.R., 138 : $633-637,1982$.

10）笠原 洋, 白羽 諴, 久山 健：外傮に上る横隔膜 破裂，とくに外偣性横隔膜へルニフについて，近大 医誌, 6：35-43，1981.

11) Lucido, J.L. and Wall, C.A.: Rupture of the diaphragm due to blunt trauma. Arch, Surg., 86 : 989-999, 1963.

12) Adamthwaite, D.N.: Traumatic diaphrag. matic hemia. 73-97.

13）土田塞昭, 倉沢隆平, 石田正珫他：気腹により診断

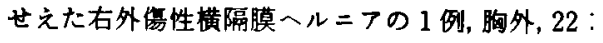
660-663, 1969.

14) Kessler, E. and Stein, A.: Diaphragmatic hernia as a long-term complication of stab wounds of the chest. Am. J. Surg., 132:34-39, 1976.

15) Armstrong, R.G.: Liver scan in the diagnosis of ruptured right hemidiaphragm with herniation of the liver. Ann. Thorac. Surg., 6: 480
$-485,1968$.

16) Clay, M.G. Munro, A.I.: Bilateral diapharag. matic hernia from blunt injury causing a Budd. Chiari Syndorome. Ann. Surg., 173: 321-324, 1971.

17) Kim, E.E., McConnell, B.J., Dillon, M., et al.: Radionuclide diagnosis of diaphragmatic rupture with hepatic herniation. Surg., $94: 36$ $-40,1983$.

18) Jallah, E.M., Frater, R.W.M. and Freeman, L. M.: Tension hepatothorax diagnosised by rapid scintiphotography. J. Thorac. Cardiovas. Surg., 59 : 283-286, 1970.

19) Bryer, J.V., Hegarty, M.M. and Howe, C.: Traumatic diaphragmatic hernia. Br. J. Surg., $65: 69-73,1978$.

20) Mansour, K.A., Clements, J.L. and Hatcher, C. R. : Diaphragmatic hernia caused by trauma : Experience with 35 cases. Ann. Surg., $41: 97$ $-102,1975$.

\title{
A STUDY OF TWO CASES OF TRAUMATIC DIAPHRAGMATIC HERNIA WITH ASSOCIATED ATYPICAL LESIONS
}

\author{
Masaaki OGAWA**, Hitoshi TAKAHASHI*, Masahiko KITANO*, Gentaro IZUMOTO** \\ Yoshiaki HAENO*, Yohsuke NAKAMURA*, Ikuhiro SAKATA** \\ and Masayuki YASUTOMI** \\ "Critical Care Medical Center Affiliated with Kinki University School of Medicine \\ (Director: Professor Masayuki YASUTOMI) \\ * First Department of Surgery, Kinki University School of Medicine
}

Traumatic diaphragmatic hernia $(\mathrm{TDH})$ is a rather rare disease, but with the increase in the number of traffic accidents and with development of a diagnostic technique many more reports have appeared. We have experienced two such cases with rare associated complications. One patient fell into shock because of pleuritis secondary to a perforated gastric ulcer, and the other developed a pericardial hematoma followed by cardiac tamponade. Both patients were saved by repairing the hernia along with gastrectomy or pericardiotomy.

The incidence of diaphragmatic injury by itself is low (13-30 percent). It is usually associated with other injuries such as ruptured spleen, hemo-pneumothorax, fractured pelvis, limb fracture and rib fracture. The complications presented here are rare with very few reported cases. Diaphragmatic injury consists of either an open or a closed injury. In Japan closed injuries are much more frequent, at a ratio of 5.5:1. TDH arises more frequently in males than in females by about 5:1, and is seen most often in persons in the age group between 20 's and 50's.

Key words: Traumatic diaphragmatic hernia, Perforated gastric ulcer, Pericardial hematoma 